\title{
THE IMPACT OF MICROFINANCE ON THE SUSTAINABILITY OF 'POOR' CLIENTS: A CONCEPTUAL REVIEW
}

\author{
Jeremiah Machingambi ${ }^{1}$
}

\begin{abstract}
:
Debates on the impact of microfinance on alleviation of poverty have revolved around two contrasting approaches that advocate sustainable lending and subsidised lending, respectively. This conceptual paper presents literature reviews on sustainable lending and the subsidised lending approaches, and their impact on the sustainability of 'poor' clients. Literature reviews highlighted that the sustainable lending paradigm mainly focuses on serving the 'active poor' clients, whilst the subsidised lending approach focuses on serving 'extremely poor' clients, respectively. 'Active poor' clients are regarded as those who have marketable skills and/or control over earning assets and are considered creditworthy borrowers. In contrast, 'extremely poor' clients have neither marketable skills nor earning assets. Smallholder farmers were used as a proxy for extremely poor clients conceptualising the notion of sustainability. A conceptual framework was developed to identify the nature of the relationship amongst constructs, informing the relationship between microfinance and poor clients (smallholder farmers). The conceptual framework has been undertaken for a study on the impact of sustainable lending approaches on smallholder farming sustainability in rural Zimbabwe.
\end{abstract}

\section{Introduction}

Microfinance has been cited as a panacea for alleviating poverty among the poor members of society. Morduch (1999) states that access to microfiance alleviates extreme poverty, thereby transforming the social and economic structures in low-income households. Thus, microfinance institutions are expected to serve clients who have been financially excluded from the formal financial services sector. In turn, accessing small loans through microfinance, enables the poor to invest in self-employment activities (Morduch, 1999). There are minimum requirements for collateral, as lenders apply for group 'lending' which depend on borrowers' neighbours co-signing loans, thereby mitigating problems created by asymmetry information between the lender and the borrower (Morduch, 1999). Poor households are traditionally excluded from the formal banking system for lack of collateral. The microfinance approach proposes new contractual structures and organisational forms that reduce the risk and cost of uncollateralised loans (Morduch, 2000). Sustainable microfinance lending combats poverty, while developing the institutional capacity of financial systems through exploring new ways to effectively lend money to poor households (Morduch, 2000).

This paper proposes a conceptual framework based on development finance theory, for assessing the impact of microfinance on the sustainability of poor clients. The conceptual framework has been undertaken for a study on the impact of sustainable lending approaches on smallholder farming sustainability in rural Zimbabwe.

'University of the Western Cape; 3710063@myuwc.ac.za 


\section{Background}

Several international and regional studies on microfinance sustainability have focused on the supply side of sustainability, which is the sustainability of Microfinance Institutions (MFIs). There is a dearth of empirical evidence on the demand-side of sustainability of microfinance for poor clients. This gap underpins the conceptualisation of the 'microfinance concept' and sustainability, with specific reference to poor clients. Poor clients are defined as households lacking collateral and that are traditionally excluded from the formal banking systems.

The background to this conceptual paper on the impact of microfinance on the sustainability of smallholder farmers in Zimbabwe, is being undertaken by the author. Studies on sustainability of smallholder farmers have equated sustainability to performance of the smallholder farming entity, the growth and yield of the farm, as well as the personal growth of the farmers. Sustainability in this study is the ability of the farmer to improve yield and growth of the venture. Farm sustainability indicators used in this study include farm income, farm profit, adoption of new farming technology and farm assets. Personal sustainability indicators in this study include household income, food security, household savings, household welfare and household assets. Related sustainability issues under investigation is the ability of extremely poor recipients to gain employment from the active poor who qualify for MFI loans.

\section{Poverty lending approach}

Modurch (2000) points out that problems of lending to poor clients includes high transaction costs per loan, determining the riskiness of potential borrowers, and monitoring progress of clients. This is accentuated when clients are small scale, poor low-income households that lack assets to put up as collateral. Microfinance programmes traditionally aligned to the poverty-lending approach were highly subsidised and underpinned by the belief that poor households could generate high returns if given credit. Also, by starting small enterprises the poor households could earn enough income to exit poverty, expand their businesses and improve their quality of life (Modurch, 2000). Governments subsidised bank loans to poor households to overcome the reluctance by banks to lend money to the poor (Modurch, 2000). Thus, the poverty-lending approach recognised the social mission of microfinance and kept interest rates low and below market-clearing levels. Adams, et al. (1984) highlight that the preferential rate polices which characterised the poverty-lending approach, repressed savings mobilisation and formal financial intermediation in general, thus leading to low economic growth. In turn, the costs of these programs mounted quickly as recipients given money with no collateral, defaulted on payments (Modurch, 2000). The default rate increased as recipients had no personal obligation to pay back the government-backed loans. The subsidised microfinance era was also characterised by little or no incentive for deposit mobilisation, and in turn subsidised lending banks, despite losing money on the lending side. Capitalised by governments they had little incentive to mobilise savings which compromised the financial system (Modurch, 2000). The core purpose of the financial system is to enhance financial intermediation between the surplus and deficit units.

When savings accounts are weighed down by restrictions, this exerts downward pressure on interest rates paid to depositors to levels below the rates charged to borrowers. The consequences of the poverty-lending approach are that real rates on deposits fall to zero or below, and savers will have little incentive to build up accounts. As a result, little savings are generated as people keep their money under the mattress or move it to non-financial assets. Subsidised credit also creates problems of corruption. Government involvement has negative consequences as the micro loans often end up subsidising wealthy politically-connected entrepreneurs, rather than poor households, in the absence of robust mechanisms to stem the leakages (Modurch, 2000). The ultimate result of the povertylending approach is high costs to lending institutions and little benefit to intended beneficiaries who fail to access affordable credit. Overall, subsidisation, inefficiency, and limited government involvement in subsidised credit, negatively impact mobilisation of savings mobilisation.

\section{Sustainable lending approach}

The sustainable-lending approach is based on the establishment of commercial microfinance, where all micro loans are fully financed by savings, commercial debt for profit investment, and retained earnings. This approach addresses the failures of the poverty-lending approach or subsidised microfinance institutions. It espouses a paradigm shift from the delivery of donor subsidised credit towards the development of sustainable financial intermediaries that capture savings, access microfinance, and lend the funds to low income borrowers at interest rates that enable full 
cost recovery and institutional self sufficiency (Robinson, 2001). In addition, Robinison (2001) highlights that savers and creditworthy borrowers can be served and repeated borrowers can be accommodated, as they expand their enterprises and qualify for larger loans, thereby becoming economically active poor and are helped from poverty. The key tenets of sustainable lending are that 'poor' households demand 'access' to credit, not 'cheap' credit and flexibility for microfinance programs to charge high interest rates without compromising outreach (Morduch, 2000).

Proponents for sustainable lending argue that MFIs that follow principles of good banking, grow without constraints imposed by donor budgets. This enables the MFls to develop the capacity to alleviate extreme levels of poverty as beneficiaries attain financial sustainability (Morduch 2000). Considerable investments by sustainable lending worldwide, include moderate return on investments in activities like livestock rearing, handicrafts and agricultural processing (Morduch, 2000:618). However, systematic assessment of who is being 'served', has been missing in conversations on sustainable lending best practices. In many ways practitioners tend to view clients that cannot pay the kind of charges required for programmes as destitute, and they qualify for direct health and education programs (or simple charity) rather than credit. Morduch (2000) reports that the target group of sustainable lending has been somewhere between destitute households and richer households, referred to as the 'core poor'. Similarly, Robinson (2001:19) points out that sustainable lending targets the economically 'active poor'. Where the economically 'active poor' are described as people who have marketable skills or control over earning assets and are or could become creditworthy borrowers and savers in commercial banks.

Ledgerwood (2013) argues that commercial microfinance is not appropriate for the extremely poor people who in most cases are badly malnourished, ill, and without skills or employment opportunities. Also, these people do not need debt, but rather need food, shelter, medicines, skills training and employment, which can be offered by governments, donor subsidies and charitable organisations. Robinison (2001) asserts that providing credit to the extremely poor and credit subsidies to the economically active poor is a futile endeavour.

Diagne and Zeller (2001) point out that microfinance enhances employment creation for the extremely poor, as the economically active poor access commercial microfinance. Thus, microfinance benefits the economically active poor directly through enabling them to establish enterprises and indirectly helps the extremely poor, who will be employed in the new ventures. From this point of view, the extremely poor may not directly benefit from commercial microfinance, but benefit indirectly from its development. Sustainable lending microfinance indirectly creates employment for the extremely poor as the economically active poor access commercial financial services (Robinson, 2000).

Overall, the sustainable-lending approach seeks to develop sustainable financial intermediaries that capture local savings and lend those funds to low income borrowers at an interest rate that enables full cost recovery and institutional self-sufficiency.

\section{Sustainability of poor clients}

Economically active poor clients are those clients who have some form of employment and are not severely fooddeficient or destitute. These people have marketable skills, or control over earning assets and become creditworthy borrowers and savers in commercial banks (Robinson, 2001). Sustainable lending microfinance targets the economically active poor. In contrast, people living in extreme poverty and existing below the minimum subsistence level, include the unemployed, severely underemployed, as well as those whose work is so poorly remunerated that their purchasing power does not permit purchasing minimum food to overcome malnutrition (Robinson, 2001). Traditionally the microfinance sector has excluded borrowers requiring small loans to finance self-employment activities (Morduch, 1999).

\section{Conceptual definitions}

\section{Development and Sustainability goals}

Development and sustainability development goals of most developing countries are derived from the UN Sustainable Development Goals. The important SDGs which relate to this study are Goal 1: no poverty; Goal 2: zero hunger and Goal 10: reducing inequality within and among countries. The national microfinance policy in Zimbabwe supports the UN SGDs. The icrofinance goals include financial inclusion (also supported by financial inclusion strategy). The notable goals include the provision for access to financial services for the marginalised that include women, rural smallholder farmers and the youth. The specific goals of the policy are to enhance 
economic equality in the economy; improve gender welfare; enhance equitable allocation of resources; enhance SME development and capacity building; and develop participation of women in mainstream economy (RBZ, 2007).

\section{Regulations}

Regulation prescribes and promotes consumer rights. Equally respective regulations prevent MFI service providers from activities that are not promotive of public confidence in the financial sector (Makuyana, 2016:376). The regulation of MFIs thus affects the supply side of microfinance and how MFIs should serve the clients. Regulation of MFls is necessary, because it levels the playing field between providers and beneficiaries. Regulation of MFls is also necessary to avert the collapse of MFls which have consequences beyond the owners and creditors. In Zimbabwe, MFls are governed by the Microfinance Act, Chapter 24:29.

Thus the regulatory framework prescribes supply side activities, compliance procedures as per the Microfinance Act, administration of MFIs, and the conduct of business with regards to lending and loan agreements.

\section{Assets or Skills Development}

The level of assets or skills affects the demand for microfinance by poor clients. The economically active poor include people who have marketable skills or control over assets (Robinson, 2001:8), where control over assets and level of marketable skills affect the access to finance from MFls. Clients who have more control over assets or who have high-level skills, are likely to have a high demand for micro loans and high chances of accessing microloans. Sustainable MFIs prefer extending loans to clients with greater control over assets and high-level skills.

\section{Demand and supply of Microfinance Services}

The demand and supply of microfinance depends on the paradigm underlying the microfinance service delivery system. Demand and supply of microfinance is subject to government regulations of MFls, as well as the skill levels of the clients. The subsidised lending paradigm is often adopted by sustainable MFls, and influence the demand and supply of microfinance. As alluded to in preceding sections, the sustainable-lending paradigm assumes that the economically poor are clients that are also profitable and self-sustainable. Assumptions underpinning the respective microfinance paradigm, determine the type of services rendered as well as target groups, and ultimately the supply and demand of microfinance.

\section{The Conceptual Framework}

Figure 1 below presents the postulated relationship amongst constructs guiding the research study. The national development and sustainability goals influence the role of MFIs, both in terms of client groups and the regulatory framework under which they operate. The sustainability agenda is embedded in the microfinance paradigm, which ultimately determines the relationship between MFls and the respective categories of poor clients. In the case of sustainable MFIs, the level of assets and skills enhance the ability of (poor) clients to borrow from MFls to start selfemployment activities, for example, small scale farming ventures. The level of skills and assets, as well as growth and development of enterprises affect the demand for microfinance by poor clients. On the other hand, the level of MFI sustainability affects the supply of MFI services. Development and sustainability goals, regulations of MFIs, demand and supply of MF services, affect the sustainability of poor client's ventures - in this case smallholder farmers. The sustainable relationship between poor clients and MFIs, enhances creation of employment for the extremely poor to work in clients' farming enterprises. In the process the workers will accumulate assets and skills and qualify for sustainable MFI loans. Regulations affect the supply of sustainable microfinance services. The level of assets and skills of clients affect the demand of sustainable microfinance services. In the proposed study, sustainable microfinance services affect smallholder farming sustainability and personal sustainability, and the level of smallholder farming sustainability affect MFI sustainability. 


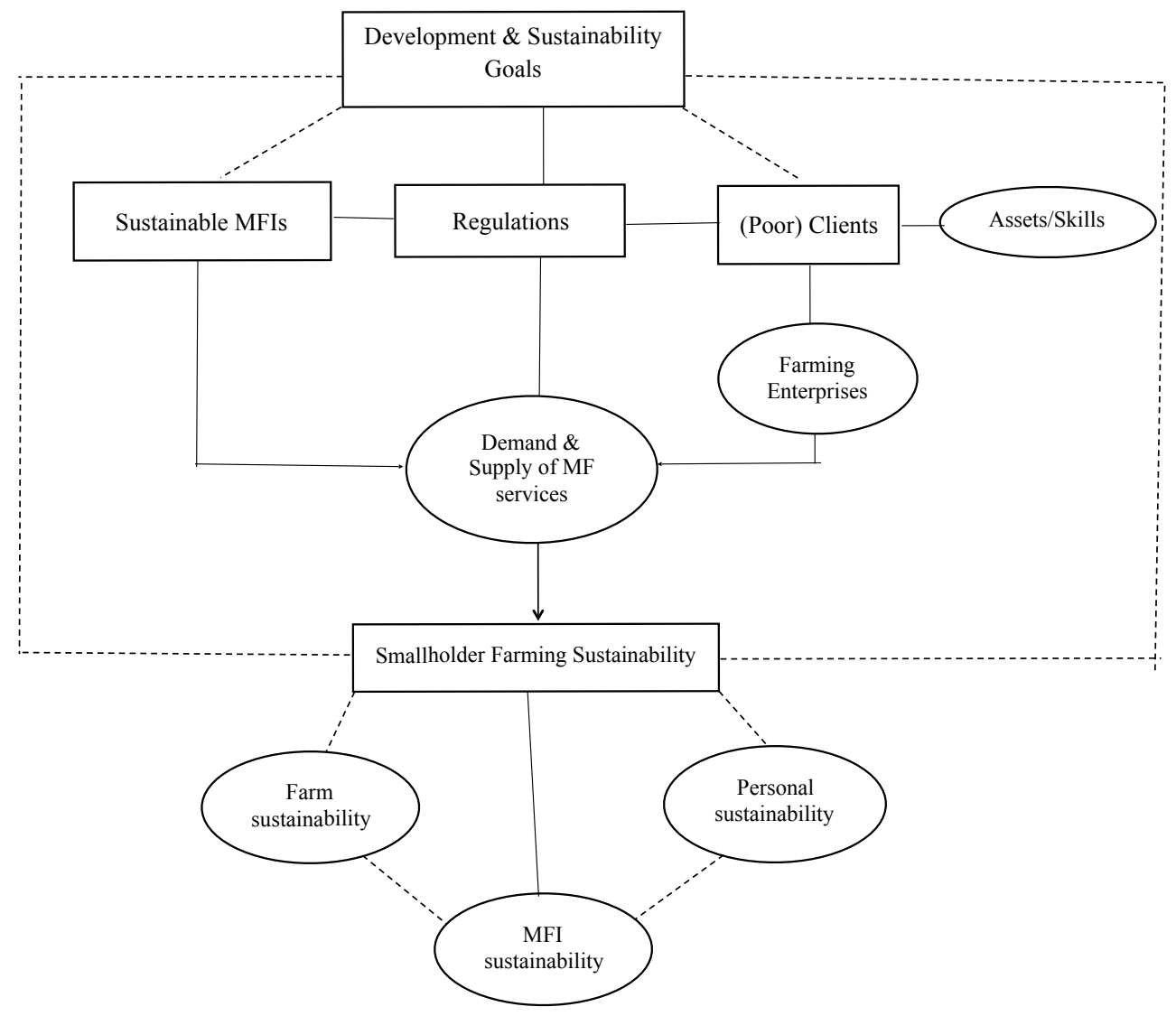

\section{Conclusion}

This paper put forward the conceptual framework explicating the relationship between sustainable microfinance and the sustainability of poor clients (smallholder farmers). The paper focused more on demonstrating the impact of a sustainable-lending approach on the sustainability of poor clients. The study focuses on smallholder farmers to demonstrate practical implications of engendering sustainability in the context of poor clients. The paper critically reviewed the subsidised and sustainable-lending approach to microfinance. The skey issues highlighted differences in terms of the target clients and implications for the sustainability of beneficiaries. The discriminating factors include skills levels and assets possessed by potential clients. In this study smallholder farming is regarded as a skill therefore smallholder farmers should be target clients for sustainable MFls.

\section{References}

Adams D W, Graham D H \& Von Pischke. (1984). Undermining rural development with cheap credit. washington D

C: Economic development Institute.

Diagne A \& Zeller M. (2001). Access to Credit and its impact on welfare in Malawi. International food Policy Research institute.

Makuyana T. (2016). Microfinance Regulation and Supervision in Zimbabwe: A Critical review. Mediterranean Journal of social sciences, 1, 376-385.

Morduch J. (1999). The Microfinance Promise. Journal of Economic Literature, XXXV11, 1569-1614.

Morduch J. (2000). The Microfinance Schism. World Development, 28(4), 617-629.

RBZ. (2007). Zimbabwe Microfinance Policy. Harare: Researve bank of Zimbabwe.

Robinson M S. (2001). The Microfinance Revolution: Sustainable Finance for the Poor. Washingtom D C: World bank. 